\title{
Economic Slowdown: Demand or Supply Induced?
}

\author{
GERALD P. DWYER, JR.
}

\begin{abstract}
䇾
ORECASTS of a decline in real product in the first quarter of 1974, accompanied by substantial increases in prices and an increase in the unemployment rate, were widely held. Preliminary data for the first quarter are consistent with these expectations, although the decline in output was greater than generally anticipated and large by historical standards. Real produot fell in the first quarter at an annual rate of 5.8 percent, the implicit price deflator rose at an annual rate of 10.8 percent, and the unemployment rate rose 0.5 percentage points to 5.2 percent.

The decline in real product, in conjunction with the slowing of real product growth in the last three quarters of 1973 , plays an especially important role in the formation of expectations about economic prospects for the rest of the year. Analysts are not agreed in their interpretations of recent business developments. Some analysts interpret the deceleration in growth of real product and the recent decline as indicative of potential weakness in aggregate demand. On the other hand, some emphasize the effects of structural problems - wage and price controls, the oil embargo, and resource allocation programs - in their interpretation of recent economic developments. To the extent that the recent performance of real product reflects these structural problems, there is little that a program of stimulating aggregate demand can do to increase output and employment for the remainder of this year.
\end{abstract}

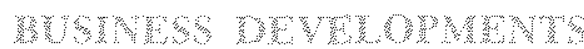

Given the severity of the current inflation, it is important to consider the extent to which recent developments reflect these structural problems. For if

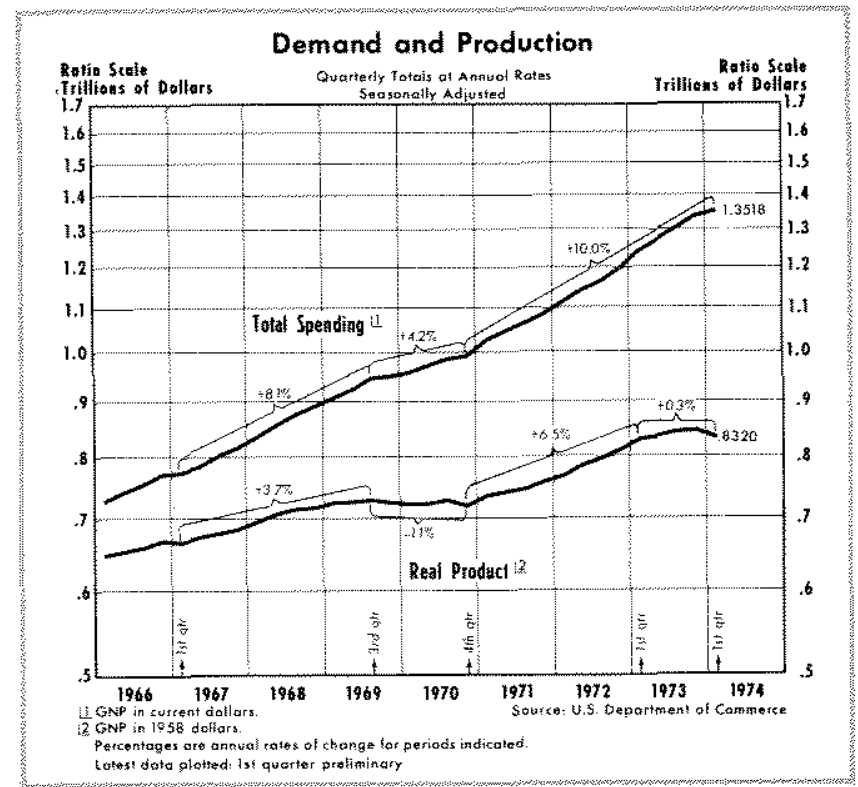

the slowing and decline in real product largely reflect structural problems, then a policy of stimulating aggregate demand would further aggravate the rate of inflation.

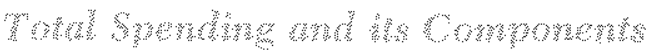

Preliminary data indicate that the growth of total spending slowed in the first quarter from the rapid pace experienced over the previous three years. Total spending increased at an annual rate of 4.3 percent in the first quarter, considerably less than the 10.5 percent rate from the fourth quarter of 1970 to the fourth quarter of 1973.

Crasuswy:-. Personal consumption expenditures, the largest single component of GNP, rose at an an- 


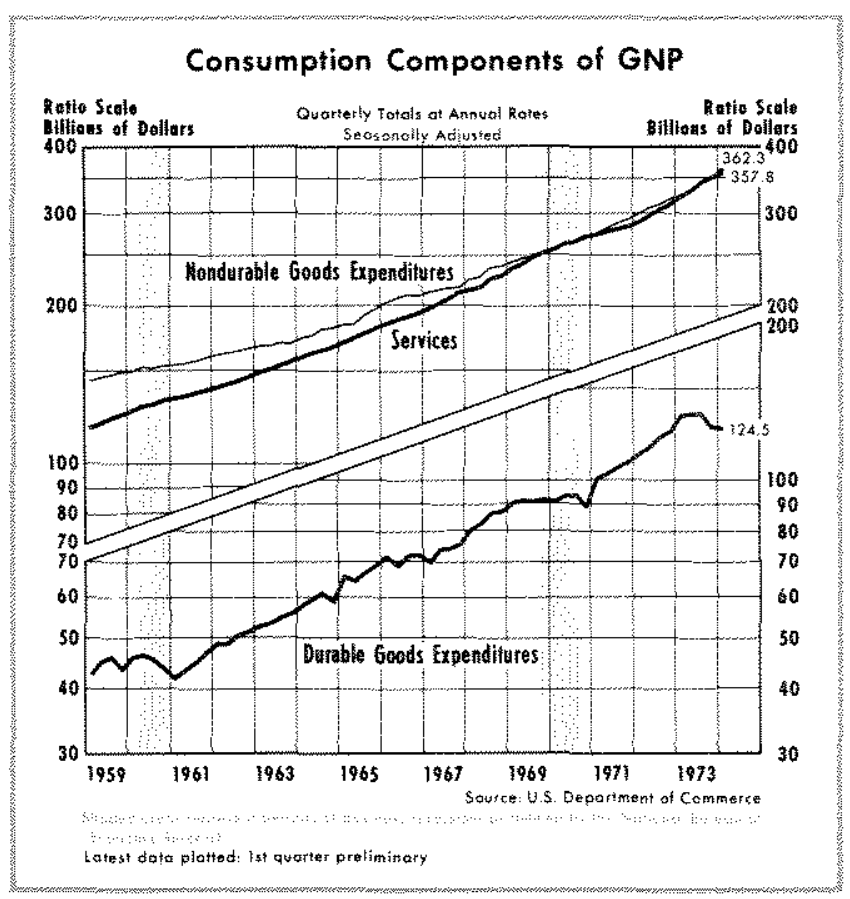

nual rate of 9.7 percent in the first quarter, about the same rate as over the previous three years. A decline in consumption expenditures on durable goods in the first quarter was more than offset by accelerated growth of consumption expenditures on nondurable goods and services. Recent reductions in spending for durable goods largely reflect a decline in purchases of autos and home appliances. Expenditures on durable goods fell at an annual rate of 3.5 percent in the first quarter, following a decline at a rate of 20 percent in the fourth quarter of last year. In comparison, expenditures on durables grew at an annual rate of 16.1 percent from the beginning of the most recent expansion in the fourth quarter of 1970 to the third quarter of 1973. Consumer spending on nondurable goods and services increased at an annual rate of 12.2 percent, compared to a 9 percent rate of increase from the fourth quarter of 1970 to the fourth quarter of 1973.

Wemenchen with substantial declines in residential construction and inventory accumulation, gross private domestic investment decreased at a 20.8 percent rate in the first quarter. In comparison, gross investment grew at an annual rate of 15.9 percent from the fourth quarter of 1970 to the fourth quarter of 1973.

A decline in auto inventories accounted for much of the slower inventory accumulation in the first quarter. This followed a high rate of inventory accumulation in the fourth quarter. Inventory investment was $\$ 7.8$ billion at an annual rate in the first quarter, less than half the $\$ 18$ billion rate in the previous quarter. Deal-

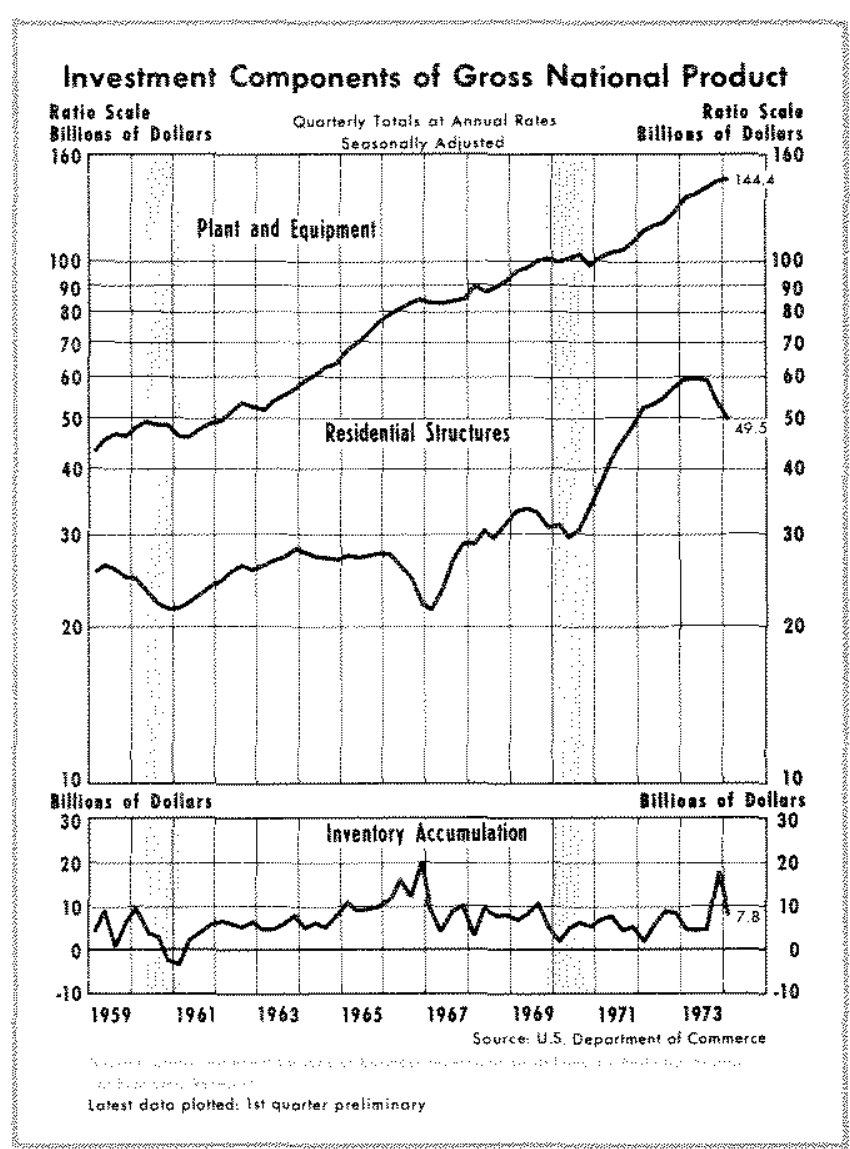

ers' inventories of autos fell at a $\$ 4.9$ billion annual rate in the first quarter, after climbing at a $\$ 4.3$ billion rate in the fourth quarter and rising at an average rate of $\$ 1.6$ billion in the first three quarters of 1973.

The decline in spending on residential structures reflected a variety of factors including higher relative costs of buying new homes, scarcity of some building materials, and higher mortgage interest rates. Investment in residential structures has decreased at an annual rate of 21.9 percent since the second quarter of 1973. This decline follows an annual growth rate of 26.4 percent from the second quarter of 1970 to the second quarter of 1973.

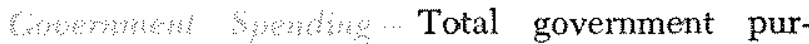
chases of goods and services increased at an accelerated 15.2 percent annual rate in the first quarter. In comparison, government purchases increased at an annual rate of 8.5 percent from the fourth quarter of 1970 to the fourth quarter of 1973. In recent years, Federal Government purchases have grown at a slower rate than state and local government purchases, but in the first quarter, purchases by the Federal Government accelerated more rapidly than purchases by state and local governments. 


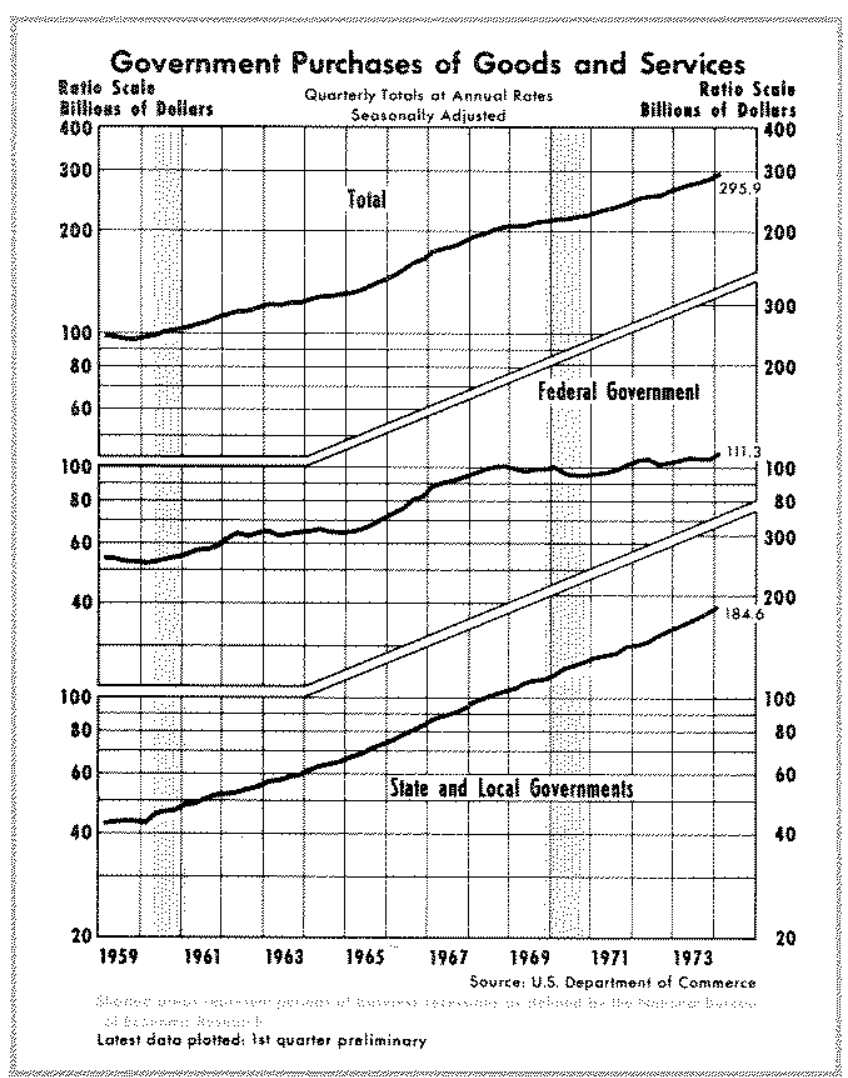

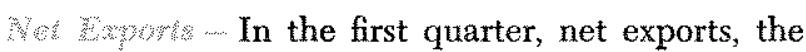
difference between the dollar value of goods and services exported and those imported, decreased to an annual rate of $\$ 9.5$ billion, compared to $\$ 12.8$ billion in the fourth quarter of 1973 . The value of exports exceeded imports by $\$ 5.8$ billion in 1973 , following a deficit of $\$ 4.6$ billion in 1972 . In addition to the devaluations of the dollar in 1971 and 1973 and the floating of exchange rates in 1973, a variety of special factors intervened to increase the growth of exports relative to imports in 1973 and early 1974 . In particular, poor harvests in other parts of the world and price controls contributed to the movement of net exports into surplus in 1973.

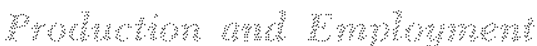

Prowumbs - The decline of real product at a 5.8 percent annual rate in the first quarter followed three quarters of growth at a 2.5 percent growth rate. The decrease of real product in the first quarter, $\$ 12.6$ billion at an annual rate, is only slightly larger than the decrease of real auto product, $\$ 12$ billion at an annual rate. The growth of real product over the last four quarters represents a deceleration from the rapid, unsustainable 6.5 percent annual rate of increase from the beginning of the most recent expansion, the fourth quarter of 1970 , to the first quarter of 1973. In com-

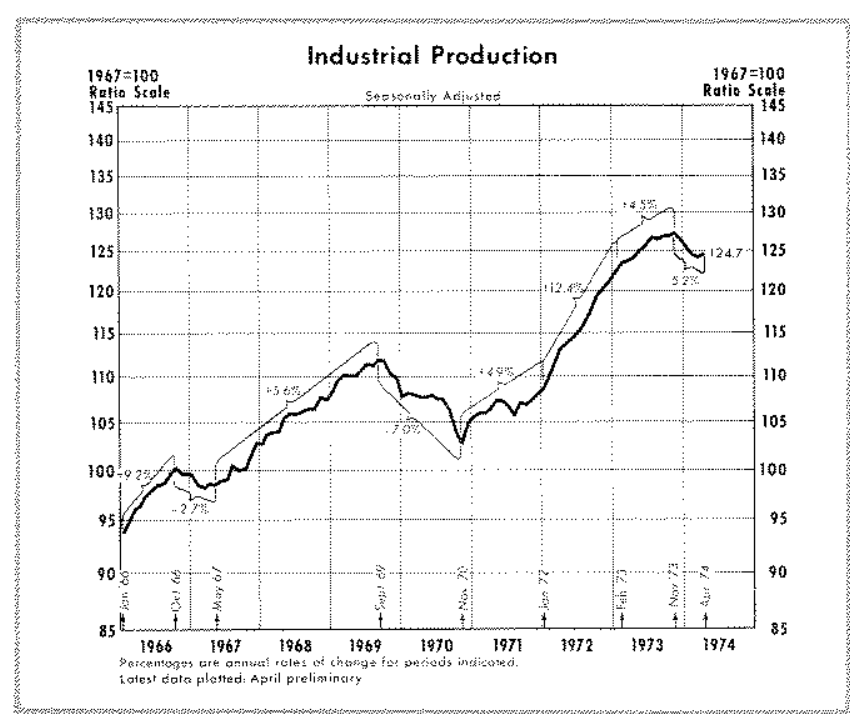

parison, real product grew at a 3.7 percent amnual rate over the period 1955-69.

Industrial production fell from November 1973 to March of this year at an annual rate of 8.2 percent. This decline followed growth of industrial production at a 4.5 percent rate from February to November of last year and a rapid 12.4 percent rate from January 1972 to February 1973.

The decline of industrial production was heavily concentrated in industries that were affected by the petroleum embargo and the associated allocation program in fourth quarter 1973 and first quarter 1974 Production by the petroleum industry itself, a relatively small component of total industrial production, declined at an annual rate of 21.6 percent from November to March. Production fell more in the transportation equipment industry, which includes motor vehicles and parts, than in any other industry; production in this industry fell at an amual rate of 38.4 percent from November to March. Electricity and natural gas utilities experienced a decline in production at an annual rate of 12.6 percent. This is not a surprising consequence of the embargo since a petroleum product, residual oll, is used to generate a significant proportion of electricity. The machinery industry and the primary and fabricated metals groups also had decreases in production at annual rates of 10 percent or more. These declines can be interpreted as the result of decreased demand by the motor vehicles and parts industry, as well as of decreased availability of energy input.

Smplaymest... The decine in real product has been accompanied by a slowing in the growth of employ. ment. Following a rapid 3.8 percent increase from the fourth quarter of 1972 to the fourth quarter of 1973 , 
total civilian employment remained virtually un* changed in the first quarter.

The unemployment rate rose from 4.7 percent in the second half of last year to 5.2 percent in the first quarter and fell to 5 percent in April of this year. Restrictions on the supply of petroleum, in conjunction with price controls on petroleum and the Government's mandatory allocation program, accounted for much of the increase in the unemployment rate from the fourth quarter of last year to the first quarter of this year. ${ }^{1}$

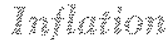

The rate of price increase accelerated sharply in the first quarter. The implicit GNP deflator rose at a 10.8 percent annual rate, following a 7.3 percent increase during 1973 . The average annual rate of increase in 1971 and 1972 was 3.5 percent.

Consumer prices rose at a 12.2 percent annual rate in the first quarter, substantially greater than the 8.4

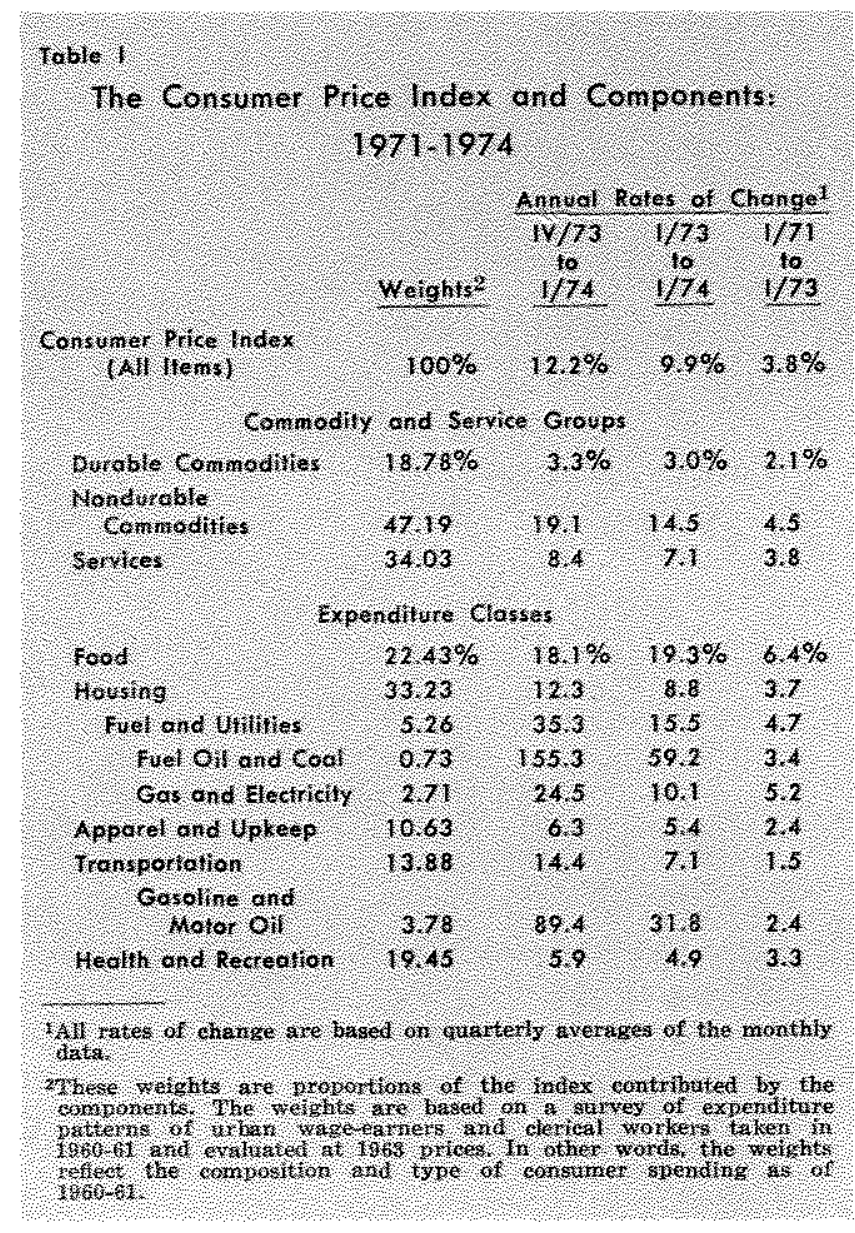

1U.S. Department of Labor, Bureau of Labor Statistics, "The Hinployment Situation: Febraary 1974," pp. $4 \mathbf{4}$. percent increase from the fourth quarter of 1972 to the fourth quarter of 1973. Fuel oil and coal prices soared at a rate of 155 percent in the first quarter, gasoline and motor oil prices climbed at an 89 percent rate, and food prices rose at a rate of 18 percent (Table I).

An increased supply of many food products, which is likely during the course of this year, will tend to decrease food prices relative to the prices of other goods and services. ${ }^{2}$ This relative decline in food prices may not, however, be reflected in actual declines of food prices; food prices may only grow slower than prices of other goods and services. In any case, recent movements of the wholesale price index for farm products and processed foods and feeds suggest that food prices will not continue to rise at recent rates. This index has varied erratically in recent months, but recently it has generally been falling or increasing more slowly than previously. From October 1972 to June 1973, prices of farm products and processed foods and feeds rose at an annual rate of 47.4 percent, and from June 1973 to April 1974, they rose at the much slower annual rate of 5.9 percent.

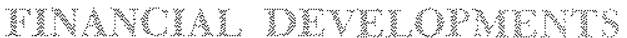

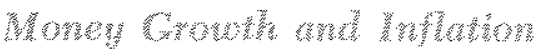

While some of the price increases in recent quarters are undoubtedly due to reductions in the supply of food and petroleum, the rate of price inflation is dominated by the growth of the money stock in the long run. ${ }^{3}$ From 1952 to 1962 , the money stock grew at an annual rate of 1.8 percent; the general level of prices also rose at an annual rate of 2 percent from 1955 to 1965. The growth of money accelerated to a 3.9 percent annual rate from 1962 to 1967; the rate of increase of prices accelerated to a 4.1 percent annual rate from 1965 to 1970 . Furthermore, it is evident from the accompanying chart that the rate of inflation has increased as growth of the money stock has increased.

More recently, the growth of money slowed in the second half of 1973 , but it is too early to tell if this represents a change in the trend growth of money. In the first quarter of this year, the money stock rose at

\footnotetext{
${ }^{2}$ An analysis of recent food price increases and the outlook is presented by Clifton B. Luttrell and Neil A. Stevens, "The 1974 Outlook for Food and Agriculture," this Review (March 1974), pp. 11-19.

${ }^{3}$ For a more extended discussion, see Darryl R. Francis, "How and Why Fiscal Actions Matter to a Monetarist," this issue of the Review, pp. 2-7.
} 




an annual rate of 5.6 percent, compared to a 4.8 percent rate in the second half of 1973 and a 7 percent average rate from the first quarter of 1970 through the second quarter of 1973 ,

The monetary base, the primary determinant of the trend growth of money, rose at an 8.7 percent annual rate in the first quarter of 1974. This is faster than the 7.5 percent annual rate of increase from the first quarter of 1970 to the fourth quarter of $1973 . .^{5}$ Since the growth rates of the monetary base and the money stock tend to be similar over extended periods of time, money stack growth can be expected to accelerate in the future unless growth of the base slows.

Money growth rates are based on guarterly averages of the revised money series. These rates of growth and those using quaterly rates based on the last month in each quarter are compared in Anatol Balbach and Jerry L. Jordan, "FOMC Policy Actions in 1973," this Review (April 1974).

5The money stock $\left(M_{1}\right)$ can be expressed as a function of the monetary base (B) and a money multiplier (m), such that $\mathrm{M}_{1}=\mathrm{mB}$. The money multiplier summarizes the decisions of the Government, banks, and the public to hold currency and bank deposits. For a presentation of this analysis, see Jerry L. Jordan, "Elements of Money Stock Determination," this Retiew (October 1969), and Albert E. Burger, The Money Supply Process (Belmont, California: Wadsworth Publishing $\mathrm{Co}$, 1971).

page 12

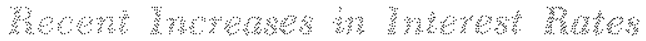

Substantial increases in the demand for credit caused short-term interest rates to climb in March, April, and early May. The prime rate on bank loans was 11 percent in early May - 250 basis points above its level in early March and 150 basis points above its level at the beginning of the year. The secondary market rate for 90-day certificates of deposit rose to 11 percent in early May, from a low of 8 percent in late February; this rate was about 9.25 percent at the beginning of the year. The discount rate, which had been 7.5 percent since August of last year, was raised to 8 percent at the end of April in response to rising money market yields.

Long-term rates rose moderately during the first four months of this year. The long-term Aaa corporate rate was about 8.35 percent in early May, about 60 basis points above its level at the beginning of the year.

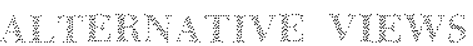

There are essentially two interpretations of the decline in real product in the first quarter. One view 
focuses on the slowing in real product growth which began in early 1973 , and attributes the slowing to a weakening of aggregate demand. This weakening in total demand, in turn, is related to a slowing in Federal expenditure growth, a decline in real money balances, and increases in interest rates. The other view is that shifts in demand, with associated adjustments, and constraints in the growth of aggregate supply were the major causes of the slowing in real product growth. This second view can be termed "constrained aggregate supply."

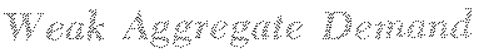

Those analysts emphasizing the weakness of aggregate demand point to the slowing of economic activity which preceded the Middle-East oil embargo. Real product grew at an annual rate of 2.9 percent from the first to the third quarter of last year, significantly less than its annual trend growth rate of 4.2 percent from 1958 to 1972. Real expenditures on consumer durable goods - expenditures on consumer durable goods adjusted for price increases - fell at a 2.7 percent annual rate from the first to the third quarter, compared to growth at a 14 percent annual rate over the previous four quarters. In addition, retail sales grew at a 3.6 percent annual rate from March to November in 1973, compared to growth at an annual rate of 13.4 percent from November 1970 to March 1973. Adjusted for price increases, retail sales actually fell during this period.

Proponents of this view also point to one or more measures of stabilization policy that indicate it was less stimulative in recent quarters than in the prior three years. The Federal budget, on a national income accounts basis, was approximately in balance during calendar year 1973, after an average deficit of $\$ 16.7$ billion from 1970 through 1972. Some analysts have referred to the recent behavior of so-called real money balances - the money stock divided by a price index - as a measure of the influence of monetary actions. ${ }^{6}$ The real money stock grew at a 0.7 percent annual rate in the first half and fell at a 2.9 percent rate in the second half of 1973 , compared to a 3 percent annual growth rate from 1970 through 1972. Also, interest rate increases in 1973 are interpreted by some analysts as an indication of monetary restraint.

6For a discussion of the problems associated with this indicator and the incorrect policy conclusions that can follow from its use, see Denis Karmosky, "Real Money Balances: A Misleading Indicator of Monetary Actions," this Retiew (February 1974), pp. 2-10.

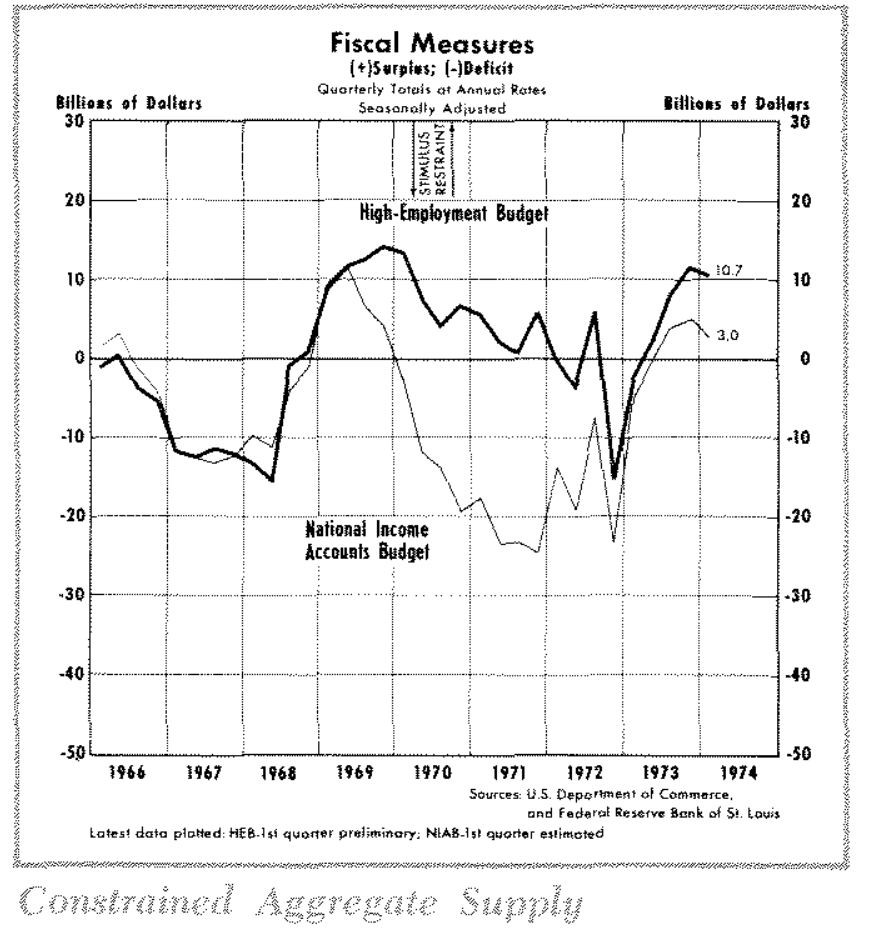

Analysts who emphasize constraints on aggregate supply and adjustments to changes in demand point out that a dip in the growth of GNP is an expected consequence of uncertainty caused by the energy situation and the reduced supplies of some goods.

These analysts also point out that the decline of real consumer purchases of durable goods or retail sales is not necessarily an indication of a decline in demand. Consumer purchases of durable goods reflect the forces of both supply and demand. And a combination of higher prices and reduced quantities sugm. gests the overwhelming influence of short-run supply considerations.

Furthermore, even though some components of total spending declined during the past year, this is not evidence of a general decrease in demand. On the contrary, a measure of total demand - total spending on goods and services - increased at an annual rate of 10.3 percent from the first to the fourth quarter of 1973 , virtually the same rate as since the beginning of the recent expansion. This is during the same period when real product grew at a slower rate.

Price controls contributed to the decline in the growth of output, according to the constrained supply view. By artificially suppressing the prices of some products which are inputs into production processes, shortages of many inputs resulted. This supply reduction would be expected to limit the production of final goods and services. 
Substantial shifts in demand occurred in the past year, and such shifts can contribute to a lower rate of output for a time. Most notable were the shifts in demand, caused by higher petroleum prices and the oil embargo, away from goods and services using relatively more gasoline and other petroleum products. Decreases in the output of these goods account for much of the decline in total real product. In addition, resources are not transferred instantaneously from previous uses to new ones. ${ }^{7}$ Thus, following a shift in demand, a decline in output and employment usually occurs for a short period of time.

A decrease in the supply of resources, in this case, petroleum, can have a similar effect on the quantity of final goods and services produced. Some industries, such as electric utilities, were affected directly by reduced allocations of petroleum. Furthermore, increases in the price of petroleum as an input in the production process have the effect of reducing output supply at its current price.

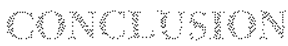

In the first quarter, real product declined, unemployment rose somewhat, and the rate of inflation

iFor a discussion of the reasons that resources are not shifted immediately, see Roger W. Spencer, "High-Employment Without Inflation: On the Attainment of Admirable Goals," this Review (September 1971), pp. 12-26. While that article specifically applies to workers, the discussion can also be applied to other resources. For more technical analysis, see Edmund S. Phelps, et al., Microeconomic Foundations of Inflation and Employment Theory (New York: W. W. Norton \& Co., Inc., 1970), esp. Amen A. Alchian, "Information Costs, "Pricing and Resource Unemployment," pp. 27-52, and Donald F. Gordon and Allan Hynes, "On the Theory of Price Dynamics," pp. 369-93. increased to greater than a 10 percent annual rate. The rather dismal performance of real product in the first quarter has been interpreted from at least two different vantage points - one emphasizing that aggregate demand is weak, the other emphasizing that supply constraints were the major factor. Many weak demand proponents base their position on such preembargo developments as the slowing in real expenditures on consumer durables and the slower growth of retail sales. According to this view, these developments are, in part, a response to the slowing in Federal expenditure growth, a decline in real money balances, and increases in interest rates.

The other interpretation of the decline in real product in the first quarter concentrates on the factors operating to reduce the supply of goods and services available for purchase. The maintenance of and subsequent dismantling of price and wage controls, the shortages of some petroleum products and the associated allocation program, and the inability to move resources immediately in response to a shift in demand - all of these factors are cited as infuencing the production of goods and services.

The data for the past year offer no clear-cut evidence that there has been a substantial weakening in aggregate demand. Marked shifts in demand have strained the ability of business to alter its product mix, especially in view of the distortion of market information and opportunities restlting from Govemment controls. Now that the embargo is ended and price controls have been removed from all sectors of the economy except the petroleum industry, these constraints on production are easing. 